\title{
数值シミュレーションを用いた実在街区における 各種ヒートアイランド対策が屋外温熱環境に与える影響の把握 EFFECTS OF VARIOUS RELAXATION METHODS FOR THE HEAT ISLAND PHENOMENON ON OUTDOOR THERMAL ENVIRONMENT IN THE PRESENT URBAN BLOCKS USING NUMERICAL SIMULATIONS
}

\author{
土屋貴史*, 大岡龍三**, 陳宏***, 黄弘**** \\ Takashi TSUCHIYA, Ryozo OOKA, Hong CHEN \\ and Hong HUANG
}

\begin{abstract}
The heat island phenomenon and urban thermal environmental degradation become serious problems in Japan. Although various relaxation measures for thermal environment have been proposed, the effects of them are different according to urban configuration. For proper urban design, it is necessary to understand quantitatively the effects of the measures. Therefore, in this paper, numerical simulations of convection, radiation and conduction were done in Otemachi area, as a high-rise office block, and in Kyobashi area, as a middle-rise office block in Tokyo, to compare the effects of the measures such as heat release point and way of air-conditioning, greening, high albedo of surface, and traffic volume. The result showed that the measures of high albedo material and greening on ground and road are effective in Otemach, and heat release point and way of air-conditioning affect very much in Kyobashi.
\end{abstract}

Keywords: The Heat Island Phenomenon, Outdoor Thermal Environment, Present Urban Blocks, Fluid ヒートアイランド現象、屋外温熱環境、実在街区

\section{1. はじめに}

近年、都市化の進行に伴うヒートアイランド現象が進行し、都市の 屋外温熱環境の悪化が顕著となってきている。この劣悪な屋外温熱環 境を改善するため、屋上、壁面、敷地を対象とした緑化や高アルベド 化、排熱の適正処理といった様々な屋外温熱環境緩和対策手法が研究、 提案されている。これらの成果は、CASBEE-HI 文1)等をはじめとした、 建築物に係わるヒートアイランド現象緩和対策の優先順位を決定す る重み付け等に利用されている。しかしながら、これらの研究は簡易 な形状の街区モデルについて検討した例が多く、実在街区を対象とし た例は少ない。また、街区形状や特性が異なれば、必要となるヒート アイランド対策の優先順位も異なることが予想される。加えて、都市 計画をする上で、これらの対策の定量的な把握を行うことは非常に重 要である。したがって、実在する様々な街区においてヒートアイラン ド対策の効果のデータを蓄積することは極めて重要であり、解析ツー ルとして、実在街区に適用する放射・対流連成解析手法の開発が必要 とされている。
本研究では、実在街区を対象に放射・対流連成解析手法を用いて各 種ヒートアイランド対策が屋外温熱環境に及ぼす影響について検討 を行った。街区によりヒートアイランド対策の効果が異なることを明 らかにするために、東京都内の 2 種類の代表的な実在業務地区、大手 町地区(高層業務地区) と京橋地区(中層業務地区)を選び、屋外温熱環 境の数值解析を行った。更に既報文 2)344)で提案された屋外温熱環境へ の影響度を利用し、建物、空調排熱、交通排熱等の熱源が屋外温熱環 境に及ぼす影響について検討をした。また、建物屋上被覆、道路・敷 地被覆、空調排熱の位置や方式の変更、交通排熱の有無等の屋外温熱 環境の緩和対策を変更したケースの比較を行い、実在学と対象として 街区形状により各種ヒートアイランド現象緩和対策の効果が異なる ことを示した。

\section{2. 解析の概要}

\section{1 シミュレーション概要}

図 1 にシミュレーション概要を示す。日時、場所、市街地形状、地

\footnotetext{
* 東京大学大学院工学系研究科建築学専攻 大学院生

** 東京大学生産技術研究所 准教授・博士 (工学)

**** 華中科技大学建築・都市計画学院 准教授・博士 (工学)

**** 東京大学生産技術研究所 助教・博士 (工学)
}

Graduate Student, Graduate School of Eng., The University of Tokyo Assoc. Prof., Institute of Industrial Science, The University of Tokyo, Dr. Eng.

Assoc. Prof., Huazhong University of Science \& Technology, Dr. Eng.

Assoc. Researcher, Institute of Industrial Science, The University of Tokyo, Dr. Eng. 


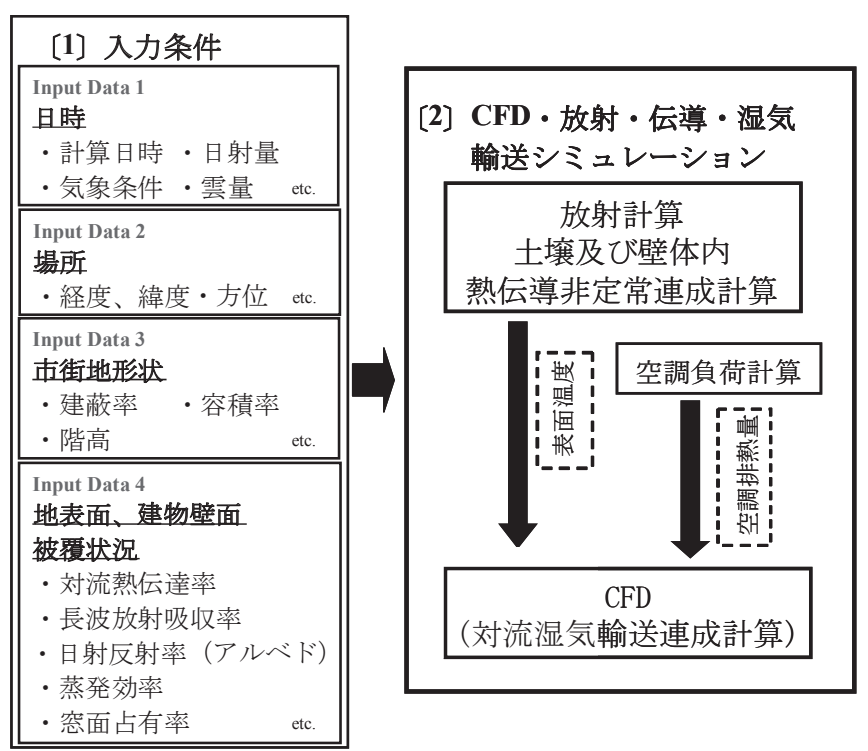

図 1 シミュレーション概要

表面および建物壁面被覆状況を入力条件として、放射・伝熱の非定常 連成シミュレーションを行う。また平成 15 年度都市における人工排 熱抑制によるヒートアイランド対策調查報告書文5)より得られた空調 排熱原単位と、街区形状データより求めた延床面積の積から空調排熱 量を求めた。交通排熱量は、同報告書の湯島線のデータより求めた。 非定常放射・伝熱連成シミュレーションの結果得られた表面温度と、 空調排熱および交通排熱を入力条件に加え、対流シミュレーションを 行った。

\section{2 対象領域および解析モデル}

高層業務地区として東京駅西側の大手町、中層業務地区として東京 駅東側の京橋を対象とした。図 2 に検討対象領域を示す。両地区共に、 道路を含む中央の数ブロックを対象とした。図 3 に解析モデルを示す。 GIS データを基として街区形状を作成し、非構造格子のメッシュに分 割した。大手町のモデルは、1,930[m]×2,720[m]×

600[m]で、379,706 メッシュとした。京橋 2,460[m]×3,630[m]×600[m] で372,000メッシュとした。

\section{3 シミュレーション条件}

表 1 に解析日時および気象条件を示す。検討対象時刻はヒートアイ ランド現象が最も顕著な夏期晴天日の午後 3 時を対象とした。放射・ 伝熱連成シミュレーションは非定常にて行い、15 時間の助走時間を 設けている。計算は 15 分ステップにて行い、建物及び土壤の計算開 始時初期温度は $26^{\circ} \mathrm{C}$ とした。非定常計算での気温、湿度はそれぞれ 1991 95 年 7 月の東京のアメダスデータのうち、快晴日のみのデー 夕を時刻別に平均した值文 6) とした。その結果、対流計算の検討対象 時刻では、気温が $31.6\left[{ }^{\circ} \mathrm{C}\right]$ 、絶対湿度が $0.0177[\mathrm{~kg} / \mathrm{kg}]$ となった。日 射量は大気透過率を 0.59 とし、太陽位置を用いて、ブーガ、ベルラ 一ゲの式より求めた。表 2 に建物および地面条件を示す。建物壁面は 暑さ $0.2[\mathrm{~m}]$ のコンクリートとし、日射反射率 0.2 、透過率 0 、長波放 射率は 0.9 とし、緑化および保水した面の蒸発効率は 0.3 とした。熱 伝導率は $1.50[\mathrm{~W} / \mathrm{m} \cdot \mathrm{K}]$ 、室内対流熱伝達率は $4.64\left[\mathrm{~W} / \mathrm{m}^{2} \cdot \mathrm{K}\right]$ とし、室 温が $26\left[{ }^{\circ} \mathrm{C}\right]$ で一定となるものとした。地面はアスファルトとし、日射 反射率 0.1 、熱伝導率 $0.73[\mathrm{~W} / \mathrm{m} \cdot \mathrm{K}]$ 、地中 $0.5[\mathrm{~m}]$ 以下では $26\left[{ }^{\circ} \mathrm{C}\right]$ で

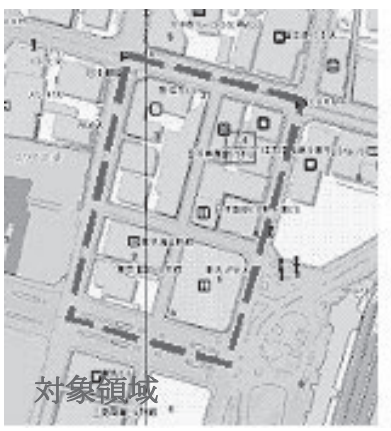

（1）大手町

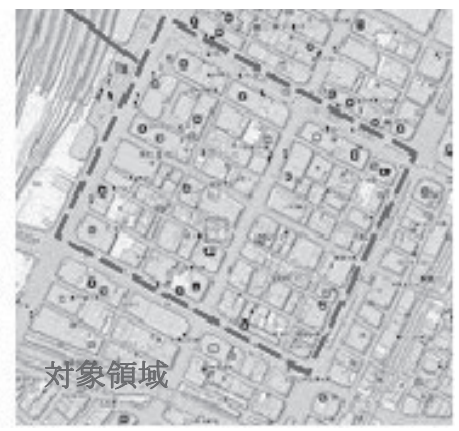

（2）京橋
図 2 検討対象領域

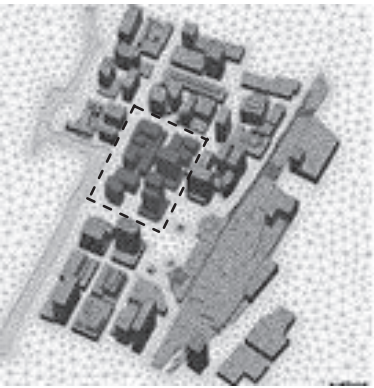

(1) 大手町

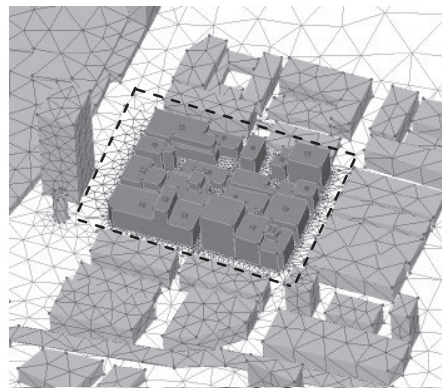

（2）京橋
図 3 解析モデル

表 1 検討対象時刻の気象条件

\begin{tabular}{|c|c|}
\hline 日 & 7月23日 \\
\hline 時刻 & 午後3時 \\
\hline 風速 & $\begin{array}{c}3.0[\mathrm{~m} / \mathrm{s}] \\
\text { (高度74.6m) }\end{array}$ \\
\hline 風向 & 南 \\
\hline 気温 & $31.6\left[{ }^{\circ} \mathrm{C}\right]$ \\
\hline 湿度 & $0.0177[\mathrm{~kg} / \mathrm{kg}]$ \\
\hline 方位角 & $83.2\left[{ }^{\circ}\right]$ \\
\hline 高度角 & $45.2\left[^{\circ}\right]$ \\
\hline $\begin{array}{c}\text { 放線面 } \\
\text { 直達日射 }\end{array}$ & $765\left[\mathrm{~W} / \mathrm{m}^{2}\right]$ \\
\hline 天空日射 & $136\left[\mathrm{~W} / \mathrm{m}^{2}\right]$ \\
\hline
\end{tabular}

表 2 建物・地面条件

\begin{tabular}{|c|c|c|}
\hline \multirow{9}{*}{$\begin{array}{l}\text { 建 } \\
\text { 物 }\end{array}$} & 壁面 & コンクリート \\
\hline & 日射反射率 & 0.2 \\
\hline & 透過率 & 0 \\
\hline & 厚さ & $0.2[\mathrm{~m}]$ \\
\hline & 熱伝導率 & $1.50[\mathrm{~W} / \mathrm{m} \cdot \mathrm{K}]$ \\
\hline & $\begin{array}{l}\text { 室内対流 } \\
\text { 熱伝達率 }\end{array}$ & $4.64\left[\mathrm{~W} / \mathrm{m}^{2} \cdot \mathrm{K}\right]$ \\
\hline & 室温 & $26\left[{ }^{\circ} \mathrm{C}\right]$ \\
\hline & $\begin{array}{c}\text { 蒸発効率 } \\
\text { (緑化·保水) }\end{array}$ & 0.3 \\
\hline & 長波放射率 & 0.9 \\
\hline \multirow{6}{*}{ 地 } & 地面 & アスファルト \\
\hline & 日射反射率 & 0.1 \\
\hline & 熱伝導率 & $0.73[\mathrm{~W} / \mathrm{m} \cdot \mathrm{K}]$ \\
\hline & $\begin{array}{c}\text { 蒸発効率 } \\
\text { (緑化·保水) }\end{array}$ & 0.3 \\
\hline & 長波放射率 & 0.95 \\
\hline & 地中 & $\begin{array}{l}0.5[\mathrm{~m}] \text { 以下は } \\
26\left[{ }^{\circ} \mathrm{C}\right] \text { に固定 }\end{array}$ \\
\hline
\end{tabular}

表 3 計算・境界条件

\begin{tabular}{|c|c|c|}
\hline \multicolumn{2}{|r|}{ 乱流モデル } & 標準 $k-\varepsilon$ \\
\hline \multicolumn{2}{|r|}{ 差分スキーム } & 風上1次差分 \\
\hline$\frac{ָ}{\underline{\omega}}$ & 風速 & $\begin{array}{l}U=U_{R} \cdot\left(Z / Z_{R}\right)^{1 / 4}, Z_{R}=74.6 U_{R}=3.0 \\
\mathrm{Z}: \text { 地上からの高さ }[\mathrm{m}] \quad \mathrm{Z}_{\mathrm{R}}: \text { 参照高度 }[\mathrm{m}] \\
\mathrm{U}: \mathrm{Z} \text { での風速 }[\mathrm{m} / \mathrm{s}] \mathrm{U}_{\mathrm{R}}: \mathrm{Z}_{\mathrm{R}} \text { での風速 }[\mathrm{m} / \mathrm{s}]\end{array}$ \\
\hline \multirow{4}{*}{ 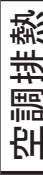 } & 風速 & $7.0[\mathrm{~m} / \mathrm{s}]$ \\
\hline & 温度 & $42\left[{ }^{\circ} \mathrm{C}\right]$ \\
\hline & 乱流エネルギー & $0.1\left[\mathrm{~m}^{2} / \mathrm{s}^{2}\right]$ \\
\hline & 散逸率 & $1\left[\mathrm{~m}^{2} / \mathrm{s}^{3}\right]$ \\
\hline \multicolumn{2}{|r|}{ 側面、天空面 } & Free Slip \\
\hline \multicolumn{2}{|r|}{ 壁面 } & 一般化対数則 \\
\hline
\end{tabular}

固定とした。また、屋外の対流熱伝達率は $11.6\left[\mathrm{~W} / \mathrm{m}^{2} \cdot \mathrm{K}\right]$ で固定とし た。図 3 に計算境界条件を示す。離散化は有限体積法、乱流モデルは 標準 $\mathrm{k}-\varepsilon$ を用い、解法アルゴリズムは SIMPLE 法、差分スキームは 風上一次差分とした。側面、天空面は Free Slip とし、流入面での風 速分布は高さ $74.6[\mathrm{~m}]$ を $3.0[\mathrm{~m} / \mathrm{s}]$ として、1/4 乗則に従うものとした。 
乱流エネルギー、散逸率は日本建築学会荷重指針文7)を参考とした。 空調排熱について、排出風速は $7.0[\mathrm{~m} / \mathrm{s}]$ 、温度は $42\left[{ }^{\circ} \mathrm{C}\right]$ 、乱流エネル ギーは $0.1\left[\mathrm{~m}^{2} / \mathrm{s}^{2}\right]$ 、散逸率は $1\left[\mathrm{~m}^{2} / \mathrm{s}^{3}\right]$ とした。壁面、地表面は一般化 対数則、天空面、側面の温度条件は固定とした。

\section{4 解析ケース}

大手町の解析ケースを表 4 に、京橋の解析ケースを表 5 に示寸。ヒ 一トアイランド現象に大きく影響していると考えられる要因の中 でも特に、被覆条件と排熱条件を変化させ、これらの変化が屋外温 熱環境に与える影響を定量的に把握する。被覆条件では緑化と高反射 化、排熱条件では、排熱位置と顕熱と潜熱の割合を変化させた。高層 業務地区である大手町では冷却塔の利用が主であると仮定し、顕熱 30\%、潜熱 70\%で排熱をすべて屋上からしていると仮定した。Case1-1 を基本ケースとし、Case1-0,1-2 は排熱条件、Case1-3, 1-4 は建物屋上 被覆条件、Case1-5, 1-6, 1-7, 1-8 は道路・敷地の被覆条件を変化させ た。Case1-9 は交通排熱を考慮したケースで、基本ケースに交通排熱 を熱フラックスとして道路に与えた。建物屋上、敷地及び道路の被覆 条件において、屋上では緑化、道路では保水性舗装材の利用とし、被 覆材料の蒸発効率を 0.0 から 0.3 に、高反射化では日射反射率を道路 部 0.1 、屋根面 0.2 から 0.5 に変更した。中層業務街区である京橋では 個別ヒートポンプが主であると仮定し、すべて顕熱にて排熱するとし た。また、ヒートポンプの室外機は建物屋上だけでなく側面にも設置 されると仮定し、各層にて $50 \%$ 、屋上にて $50 \%$ を排熱するとした。 Case2-1 を基本ケースとし、Case2-0、Case2-2、Case2-3 で排熱の有無、 顕熱潜熱の割合、排熱位置を変更した。Case2-4、Case2-5 では屋上 被覆条件を、Case2-6、Case2-7 では道路・敷地被覆条件を変更した。 Case2-8 を大手町同様に交通排熱を加えたケースとした。

表 6 屋外温熱環境への影響度

・建物壁面からの顕熱フラックスの屋外温熱環境への影響度

$$
i m p_{j w}=\frac{\Delta T_{\text {airj }}}{\Delta T_{\text {walli }}}\left(T_{\mathrm{i}}-T_{\text {ai }}\right)
$$

・ 建築設備からの排熱の屋外温熱環境への影響度

$$
i m p_{j b}=\left(T_{\mathrm{jb}}-T_{j}\right)
$$

・交通排熱の屋外温熱環境への影響度

$$
\operatorname{imp}_{j r}=\left(T_{\mathrm{jr}}-T_{j}\right)
$$

記号

$\mathrm{imp}_{\mathrm{jw}}: \mathrm{j}$ セルにおける建物壁面の影響度

$\mathrm{imp}_{\mathrm{jb}}: \mathrm{j}$ セルにおける建物設備からの排熱の影響度

$i_{\mathrm{mp}} \mathrm{jr}$ : j セルにおける交通排熱の影響度

$\Delta \mathrm{T}_{\text {airj }}: j$ セルにおける気温上昇分（壁面温度を上昇したケー ス一基本ケース)

$\Delta \mathrm{T}_{\mathrm{wa} 11 \mathrm{i}}$ : $\mathrm{i}$ 壁面における壁面温度上昇分（i：北、南、東、西、 屋上) $\mathrm{T}_{\mathrm{i}} ： \mathrm{i}$ 壁面の表面温度

$\mathrm{T}_{\mathrm{ai}}: \mathrm{i}$ 壁面近傍第 1 セルの平均気温

$\mathrm{T}_{\mathrm{jb}}$ : 空調排熱を考慮した時の $\mathrm{j}$ セルの気温

$\mathrm{T}_{\mathrm{jr}}$ : 交通排熱を考慮した時の $\mathrm{j}$ セルの気温

\section{3. 屋外温熱環境への影響度の概要}

ここで、屋外の温熱環境形成要因を定量的に評価するための影響度 の定義を行う。屋外温熱環境への影響度は、屋外空間における顕熱に 着の定義を行う。屋外温熱環境への影響度は、屋外空間における顕熱 に着目し、熱源として建物壁面、地面、建物の排熱口等の各熱源の影 響により生じる昇温（降温）分布から空間内における各点の気温形成 に与える影響を評価するものである。本報で定義する建物各壁面から の屋外温熱環境形成への影響度を表 6 亿示寸。建物壁面からの顕熱入

\begin{tabular}{|c|c|c|c|c|c|c|c|c|c|}
\hline \multirow[b]{2}{*}{ Case } & \multicolumn{4}{|c|}{ 道路・敷地 } & \multicolumn{2}{|c|}{ 屋上 } & \multicolumn{2}{|c|}{ 空調 } & \multirow{2}{*}{$\begin{array}{l}\text { 検討 } \\
\text { 事項 }\end{array}$} \\
\hline & $\begin{array}{l}\text { 保水 } \\
\text { 建材 }\end{array}$ & \begin{tabular}{|l} 
高反 \\
射率
\end{tabular} & \begin{tabular}{|l|} 
交通 \\
排熱
\end{tabular} & \begin{tabular}{|c|} 
緑地 \\
率
\end{tabular} & 緑化 & \begin{tabular}{|c} 
高反 \\
射
\end{tabular} & 顕熱 & 潜熱 & \\
\hline $1-0$ & $0 \%$ & $0 \%$ & 無 & $0 \%$ & $0 \%$ & $0 \%$ & $0 \%$ & $0 \%$ & 排熱無 \\
\hline $1-1$ & $0 \%$ & $0 \%$ & 無 & $0 \%$ & $0 \%$ & $0 \%$ & $30 \%$ & $70 \%$ & 基本 \\
\hline $1-2$ & $0 \%$ & $0 \%$ & 無 & $0 \%$ & $0 \%$ & $0 \%$ & $100 \%$ & $0 \%$ & $\begin{array}{c}\text { 屋上 } \\
\text { 顕熱 } 100 \%\end{array}$ \\
\hline $1-3$ & $0 \%$ & $0 \%$ & 無 & $0 \%$ & $100 \%$ & $0 \%$ & $30 \%$ & $70 \%$ & 屋上緑化 \\
\hline $1-4$ & $0 \%$ & $0 \%$ & 無 & $0 \%$ & $0 \%$ & $100 \%$ & $30 \%$ & $70 \%$ & $\begin{array}{l}\text { 屋上 } \\
\text { 高反射 }\end{array}$ \\
\hline $1-5$ & $100 \%$ & $0 \%$ & 無 & $100 \%$ & $0 \%$ & $0 \%$ & $30 \%$ & $70 \%$ & $\begin{array}{l}\text { 道路保水 } \\
\text { 敷地緑化 } \\
\end{array}$ \\
\hline $1-6$ & $\underline{0 \%}$ & $0 \%$ & 無 & $100 \%$ & $0 \%$ & $0 \%$ & $30 \%$ & $70 \%$ & 敷地緑化 \\
\hline $1-7$ & $0 \%$ & $100 \%$ & 無 & $0 \%$ & $0 \%$ & $0 \%$ & $30 \%$ & $70 \%$ & $\begin{array}{c}\text { 道路 } \\
\text { 高反射 }\end{array}$ \\
\hline $1-8$ & $0 \%$ & $100 \%$ & 無 & $100 \%$ & $0 \%$ & $0 \%$ & $30 \%$ & $70 \%$ & $\begin{array}{l}\text { 道路高反射 } \\
\text { 敷地緑化 }\end{array}$ \\
\hline $1-9$ & $0 \%$ & $0 \%$ & 有 & $0 \%$ & $0 \%$ & $0 \%$ & $30 \%$ & $70 \%$ & 交通排熱 \\
\hline
\end{tabular}
ラックスの影響度については以下のように考えられる。実環境状態に

表 4 大手町計算ケース (すべて屋上排熱)

\begin{tabular}{|c|c|c|c|c|c|c|c|c|c|}
\hline \multirow[b]{2}{*}{ Case } & \multicolumn{4}{|c|}{ 道路・敷地 } & \multicolumn{2}{|c|}{ 屋上 } & \multicolumn{2}{|c|}{ 空調 } & \multirow{2}{*}{$\begin{array}{l}\text { 検討 } \\
\text { 事項 }\end{array}$} \\
\hline & $\begin{array}{l}\text { 保水 } \\
\text { 建材 }\end{array}$ & $\begin{array}{l}\text { 高反 } \\
\text { 射率 }\end{array}$ & $\begin{array}{l}\text { 交通 } \\
\text { 排熱 }\end{array}$ & $\begin{array}{l}\text { 緑地 } \\
\text { 率 }\end{array}$ & 緑化 & \begin{tabular}{|c} 
高反 \\
射 \\
\end{tabular} & 顕熱 & 潜熱 & \\
\hline $2-0$ & $0 \%$ & $0 \%$ & 無 & $0 \%$ & $0 \%$ & $0 \%$ & $0 \%$ & $\underline{0 \%}$ & 排熱無 \\
\hline $2-1$ & $0 \%$ & $0 \%$ & 無 & $0 \%$ & $0 \%$ & $0 \%$ & $100 \%$ & $0 \%$ & $\begin{array}{l}\text { 基本 } \\
\text { 个ース }\end{array}$ \\
\hline $2-2$ & $0 \%$ & $0 \%$ & 無 & $0 \%$ & $0 \%$ & $0 \%$ & $10 \%$ & $90 \%$ & $\begin{array}{c}\text { 屋上 } \\
\text { 顕熱 } 10 \%\end{array}$ \\
\hline $2-3$ & $0 \%$ & $0 \%$ & 無 & $0 \%$ & $0 \%$ & $0 \%$ & $100 \%$ & $0 \%$ & $\begin{array}{c}\text { 屋上 } \\
\text { 顕熱 } 100 \%\end{array}$ \\
\hline $2-4$ & $0 \%$ & $0 \%$ & 無 & $0 \%$ & $100 \%$ & $0 \%$ & $100 \%$ & $0 \%$ & $\begin{array}{l}\text { 屋上 } \\
\text { 緑化 }\end{array}$ \\
\hline $2-5$ & $0 \%$ & $0 \%$ & 無 & $0 \%$ & $0 \%$ & $100 \%$ & $100 \%$ & $0 \%$ & $\begin{array}{l}\text { 屋上 } \\
\text { 高反射 }\end{array}$ \\
\hline $2-6$ & $100 \%$ & $0 \%$ & 無 & $100 \%$ & $0 \%$ & $0 \%$ & $100 \%$ & $0 \%$ & $\begin{array}{l}\text { 道路 } \\
\text { 保水 }\end{array}$ \\
\hline $2-7$ & $0 \%$ & $\underline{100 \%}$ & 無 & $0 \%$ & $0 \%$ & $0 \%$ & $100 \%$ & $0 \%$ & $\begin{array}{l}\text { 道路 } \\
\text { 高反射 }\end{array}$ \\
\hline $2-8$ & $0 \%$ & $0 \%$ & 直 & $0 \%$ & $0 \%$ & $0 \%$ & $100 \%$ & $0 \%$ & $\begin{array}{l}\text { 交通 } \\
\text { 排熱 }\end{array}$ \\
\hline
\end{tabular}

表 5 京橋計算ケース

(各層 50\%屋上 50\%排熱、2-2・2-3 は屋上排熱 100\%)

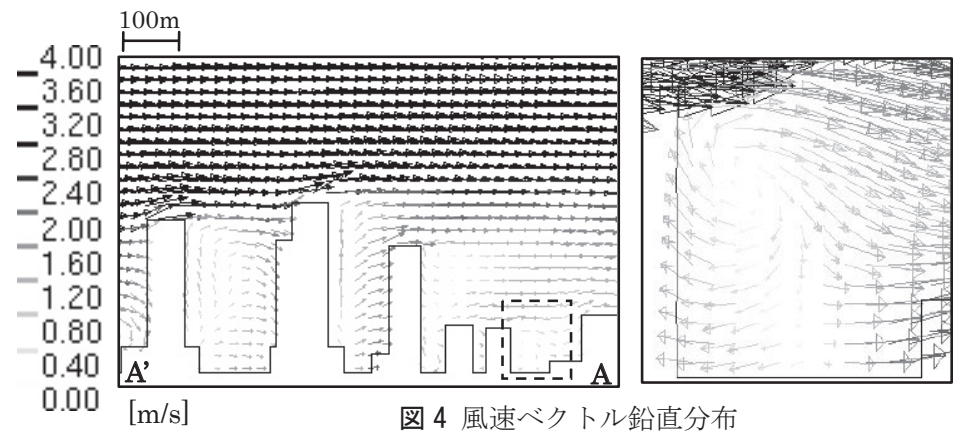

(A-A'断面) 


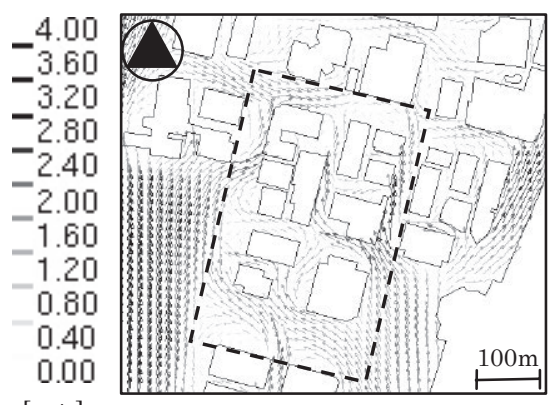

$[\mathrm{m} / \mathrm{s}]$ 図 5 風速ベクトル水平分布 (高さ $1.5 \mathrm{~m}$ )

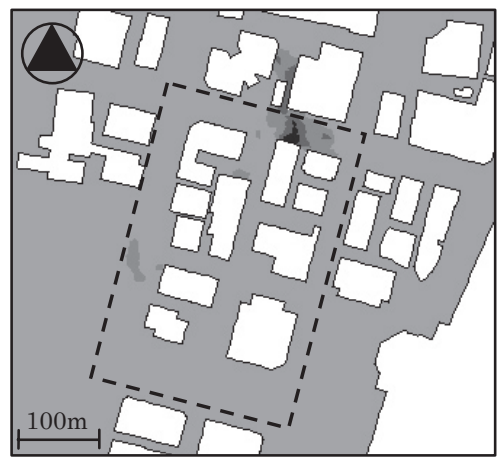

(1) 排熱無し (Case1-0)

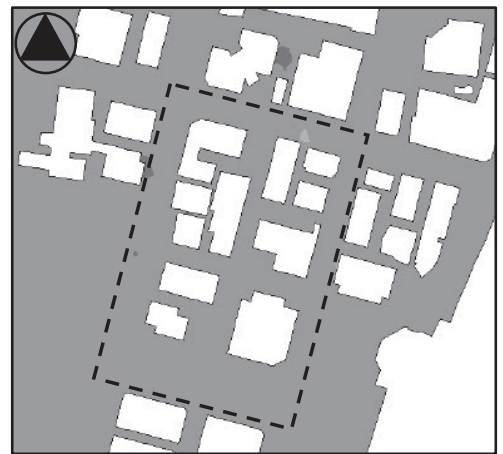

（4）屋上高反射（Case1-4）

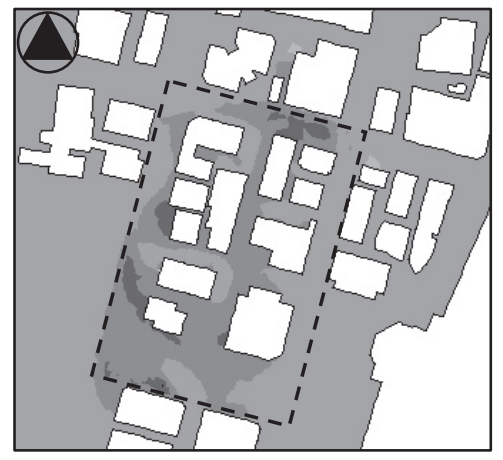

（7）道路高反射（Case1-7）

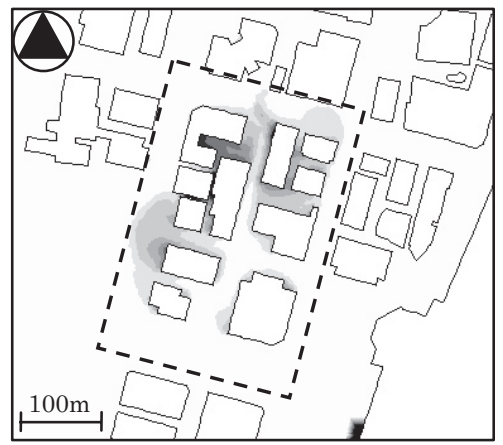

（1）建物全体

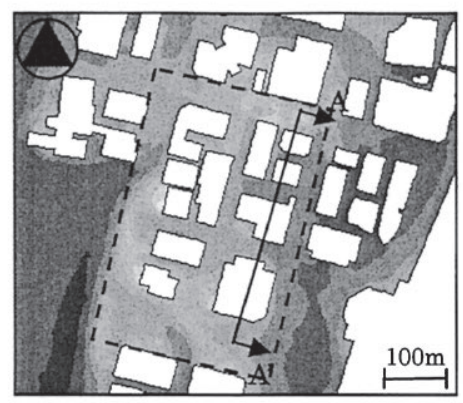

図 6 気温水平分布 (基本ケース) (高さ $1.5 \mathrm{~m}$ )

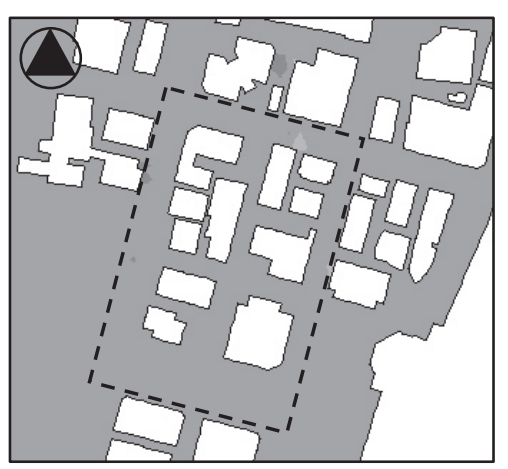

（2）屋上顕熱 100\% (Case1-2)

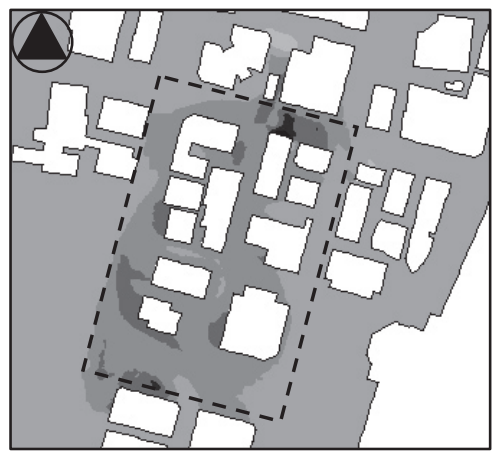

（5）道路保水·敷地緑化 (Case1-5)

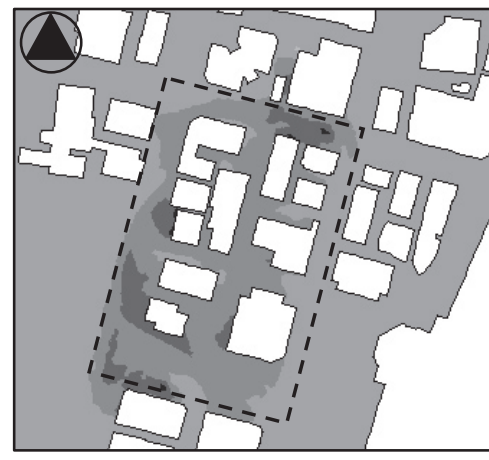

（8）道路高反射·敷地緑化 (Case1-8) 図 8 基本ケースとの温度差（高さ $1.5 \mathrm{~m}$ )

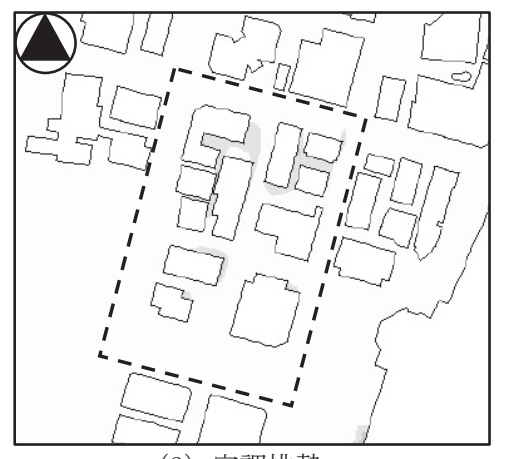

図 9 影響度の水平分布 (高さ $1.5 \mathrm{~m}$ )

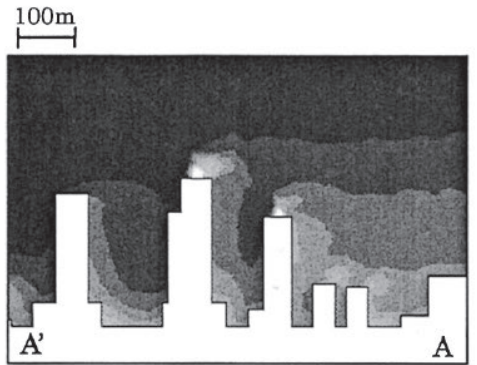

図 7 気温鉛直分布 ( $\mathrm{A}-\mathrm{A}^{\prime}$ 断面)
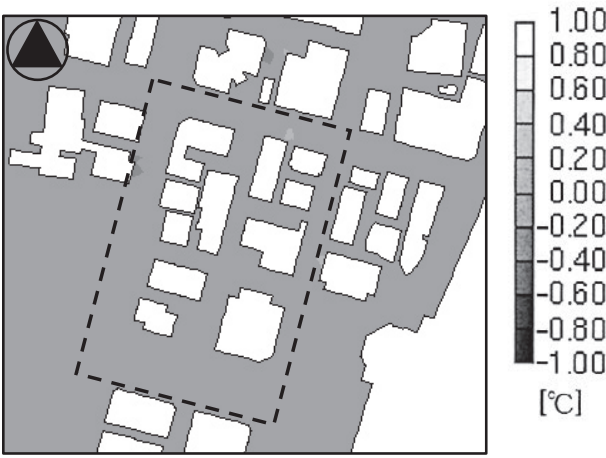

（3）屋上緑化 (Case1-3)

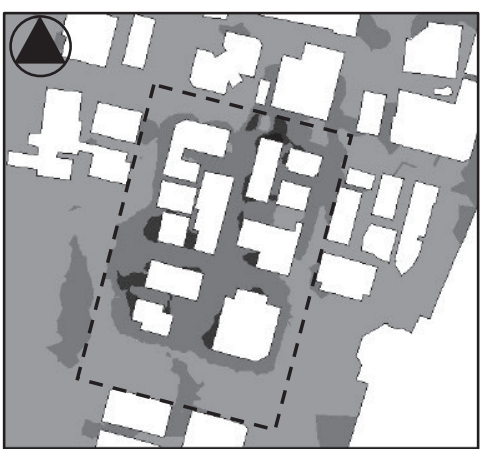

（6）敷地緑化（Case1-6）

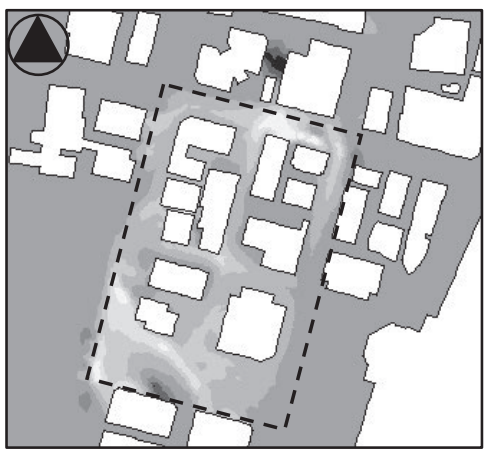

（9）交通排熱（Case1-9）

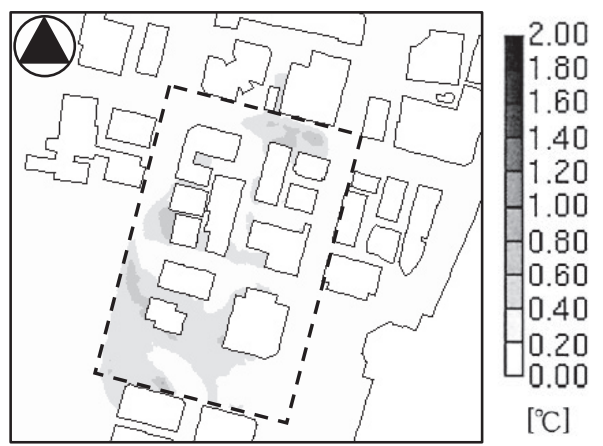

（3）交通排熱 
表 7 平均気温·平均風速

(高さ $1.5 \mathrm{~m})$

\begin{tabular}{|c|c|c|}
\hline Case & 平均気温 $\left({ }^{\circ} \mathrm{C}\right)$ & 平均風速 $(\mathrm{m} / \mathrm{s})$ \\
\hline $1-0$ & 32.96 & 1.47 \\
\hline $1-1$ & 32.96 & 1.51 \\
\hline $1-2$ & 32.96 & 1.49 \\
\hline $1-3$ & 32.96 & 1.49 \\
\hline $1-4$ & 32.96 & 1.49 \\
\hline $1-5$ & 32.82 & 1.45 \\
\hline $1-6$ & 32.93 & 1.48 \\
\hline $1-7$ & 32.86 & 1.49 \\
\hline $1-8$ & 32.82 & 1.48 \\
\hline $1-9$ & $\underline{\mathbf{3 3 . 1 6}}$ & $\underline{\mathbf{1 . 5 8}}$ \\
\hline
\end{tabular}

おける壁面から空間に放散する顕熱、また壁面温度が $\Delta \mathrm{T}_{\mathrm{walli}}$ 上昇し た時に放散する顕熱をそれぞれ(4)、(5)式で示す。

$$
\begin{aligned}
& q=\alpha\left(T_{i}-T_{a i}\right) \\
& q+\Delta q=\alpha\left(T_{i}+\Delta T_{\text {wall }}-T^{\prime}{ }_{a i}\right)
\end{aligned}
$$

ここで $\alpha$ は対流熱伝達率、 $\mathrm{T}_{\mathrm{ai}}, \mathrm{T}_{\mathrm{ai}}$ はそれぞれの条件における壁面近 傍の外気温度である。また、（4）と（5）式から、

$$
\Delta q=\alpha\left(\Delta T_{\text {walli }}-\left(T_{a i}^{\prime}-T_{a i}\right)\right)
$$

となる。ここで、ここには示せぬが、経験的に外気温変化 $\left(\mathrm{T}^{\prime}{ }_{\mathrm{ai}}-\mathrm{T}_{\mathrm{ai}}\right)$ は $\Delta \mathrm{T}_{\text {walli }}$ のせいぜい $20 \%$ 以内であるので、これを無視すると、 $\Delta \mathrm{q}$ は次の（7）式となる。

$$
\Delta q=\alpha \Delta T_{\text {walli }}
$$

更に、流れ場を固定した時に温度輸送方程式の線形性を考慮すると、 熱源となる壁面の顕熱放散とそれによる $\mathrm{j}$ 点の空気温度の寄与分 (=impj) と顕熱放散増加分 $\Delta q$ と同じ点の顕熱放散量増加による空気 温度上昇分 $\left(\Delta \mathrm{T}_{\text {airj }}\right)$ の関係は(8)式となる。

$$
\text { imp }_{j w} / q=\Delta T_{\text {airj }} / \Delta q
$$

この時に空間内 $\mathrm{j}$ セルにおける顕熱フラックス $\mathrm{q}$ によっもたらさ れる気温形成分 (影響度) は(9)式により算出することが可能である。

$$
\begin{aligned}
\operatorname{imp}_{j w} & =\frac{\Delta T_{\text {airj }}}{\Delta q} \times q \\
& =\frac{\Delta T_{\text {airj }}}{\alpha \Delta T_{\text {walli }}} \times \alpha\left(T_{i}-T_{a i}\right) \\
& =\frac{\Delta T_{\text {airj }}}{\Delta T_{\text {walli }}}\left(T_{i}-T_{a i}\right)
\end{aligned}
$$

記号 : 表 6 中の記号

$\Delta \mathrm{q}$ : 壁面温度の上昇により壁面から放散する顕熱の増加量 建物壁面からの顕熱フラックスの屋外温熱環境への影響度は、建物壁 面からの顕熱放散に着目し、建物の各壁面の影響により屋外空間にお ける各点の気温形成に与える影響を評価するものである。各壁面の影 響度を算出する際に、まず、通常の CFD 解析を行い、風速と気温の 空間分布を求める。次に、風速分布を固定し、壁面の表面温度を $\Delta$ $\mathrm{T}_{\text {walli }}$ だけ上昇させて、温度場のみの再計算を行う。新たな気温の空 間分布を算出し、（1）式により壁面の影響度を算定する。ここで(1) 式における $\left[\Delta \mathrm{T}_{\text {airj }} / \Delta \mathrm{T}_{\text {walli }}\right]$ は原山ら文8)の NCRO1 と同じであり、壁 面温度が $1\left[{ }^{\circ} \mathrm{C}\right]$ 上昇した時の周辺外気の温度上昇分を示す。本報では これに壁面温度と近傍外気温度の差を乗ずることにより建物壁体か

らの顕熱フラックスが屋外温熱環の地点の気温を何度上昇させてい るかを意味する。導出の過程は注 1 参照。また、建物からの人工排 熱による屋外温熱環境への影響度は、人工排熱を排出しない状態に対 して、人工排熱を排出した時に屋外環境における各点の気温の変化量 により評価する。これは原山ら文8)の NCRO2 に排熱量そのものを乗 じた值に相当し、人工排熱による気温上昇分を意味する。

\section{4. 解析結果}

\section{1 大手町}

(1)風速: 図 5 に Case1-1 の高さ $1.5[\mathrm{~m}]$ における風速ベクトルの水平分 布を示す。全ケースにおいて、解析領域における風速ベクトルの水平 分布は同じ傾向を示した。建物の風下側では急激に風速の水平成分が 減少する傾向が見られた。図 4 に図 6 中の $\mathrm{A}-\mathrm{A}^{\prime}$ 断面の風速ベクトル 鉛直分布および点線部の拡大図を示す。水平分布同様、全ケースにお いて、解析領域における風速ベクトルの鉛直分布は同じ傾向を示した。 Case1-0 のみ屋上からの空調排熱がないため、排熱口付近の鋁直成分 が小さくなる。点線部のように、屋上付近から下向きに風が吹き降ろ され、循環流が発生していることがわかる。表 7 に各ケースの対象領 域の平均風速を示す。Case1-1 に比べ、道路・敷地被覆を変化させる Case1-5，1-6，1-7，1-8 では地表面の温度低下により平均風速は若干低 くなり、交通排熱を考慮した Case1-9 では、地面の熱フラックスの増 加により平均風速が約 $0.1[\mathrm{~m} / \mathrm{s}]$ 上昇した。

(2) 気温 : 図 7 に気温鉛直分布を示す。屋上からの空調排熱が地表面 付近の気温にほとんど影響を与えていてないことがわかる。図 6 に Case1-1 の高さ $1.5[\mathrm{~m}]$ における気温の水平分布を、図 8 に高さ $1.5[\mathrm{~m}]$ における各ケースと基本ケースとの気温差を示す。建物風下側にて気 温が上昇する傾向があり、気温は約 $34.6\left[{ }^{\circ} \mathrm{C}\right]$ まで上昇した。風通しの 悪い道路において、熱が排出されず気温が比較的上昇しやすく、風通 しが良い道路において気温上昇が比較的抑えられる傾向が見られた。 各ケースの気温差を見ると、基本ケースと比心゙、屋上被覆を変化させ た Case1-3, 1-4 では、高さ 1.5[m]での気温変化はほとんどなく、屋上 高反射・緑化等の緩和対策は歩行者レベルに効果が殆じないことが示 された。これは検討対象領域における全ての建物は高層建築であるた めと考えられる。これに対し、Case1-5，1-6，1-7，1-8 では、平均気温 は約 $0.1\left[{ }^{\circ} \mathrm{C}\right]$ 程度低下した。特に図 8 に示すように、道路・敷地の保 水・緑化ケースでは検討対象領域全体で気温が低下し、最大 $0.8\left[{ }^{\circ} \mathrm{C}\right]$ 程度気温が低下した。表 7 の高さ $1.5[\mathrm{~m}]$ での各ケース毎の平均気温 をみると、排熱条件を変えたケース、屋上の被覆条件を変えたケース では、平均気温の変化は見られなかった。これは排熱位置、被覆条件 の変更が高層建築の屋上であるため、人体領域への影響がほとんどな

表 9 平均気温.平均風速 (高さ $1.5 \mathrm{~m}$ )

\begin{tabular}{|c|c|c|}
\hline Case & 平均気温 $\left({ }^{\circ} \mathrm{C}\right)$ & 平均風速 $(\mathrm{m} / \mathrm{s})$ \\
\hline $2-0$ & 32.99 & 0.90 \\
\hline $2-1$ & 33.19 & 1.19 \\
\hline $2-2$ & 32.97 & 1.10 \\
\hline $2-3$ & 33.07 & 1.26 \\
\hline $2-4$ & 33.20 & 1.16 \\
\hline $2-5$ & 33.18 & 1.15 \\
\hline $2-6$ & 33.05 & 1.17 \\
\hline $2-7$ & 33.07 & 1.25 \\
\hline $2-8$ & $\underline{\mathbf{3 3 . 5 7}}$ & $\underline{\mathbf{1 . 2 8}}$ \\
\hline
\end{tabular}

表 10 平均影響度 (高さ $1.5 \mathrm{~m})\left({ }^{\circ} \mathrm{C}\right)$

\begin{tabular}{|c|c|}
\hline 東 & 0.005 \\
\hline 西 & 0.052 \\
\hline 南 & 0.117 \\
\hline 北 & 0.020 \\
\hline 屋上 & 0.108 \\
\hline 全壁面 & 0.303 \\
\hline 空調排熱 & 0.205 \\
\hline 交通排熱 & 0.381 \\
\hline \multicolumn{2}{|l}{} \\
\multicolumn{2}{|l}{}
\end{tabular}




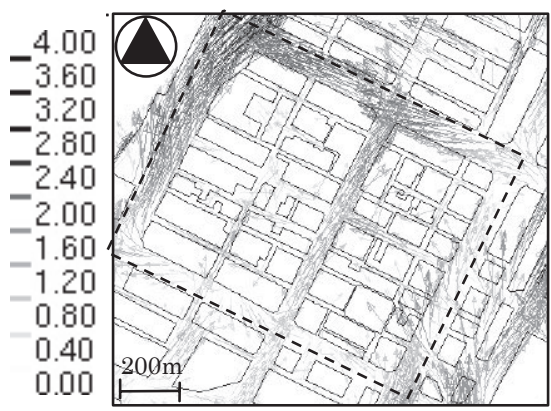

$[\mathrm{m} / \mathrm{s}]$ 図 10 風速ベクトル水平分布

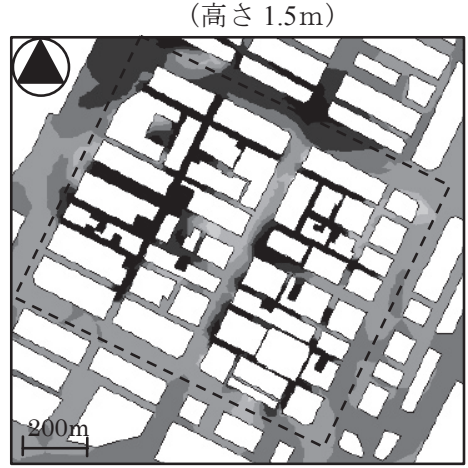

(1) 排熱無 (Case2-0)

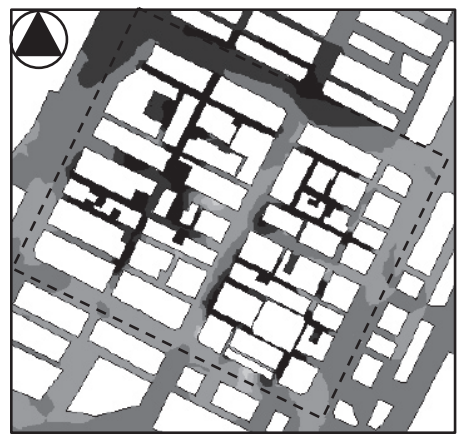

（3）屋上顕熱 100\%（Case2-3）

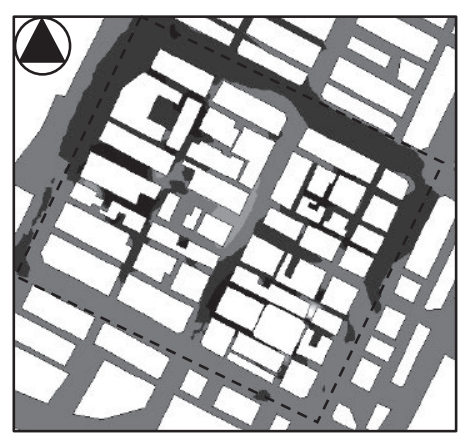

（6）道路保水（Case2-6）

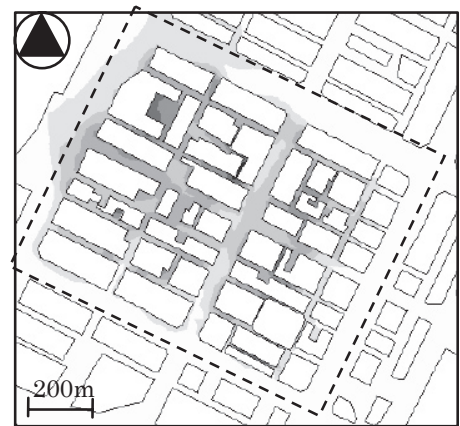

(1) 建物全体

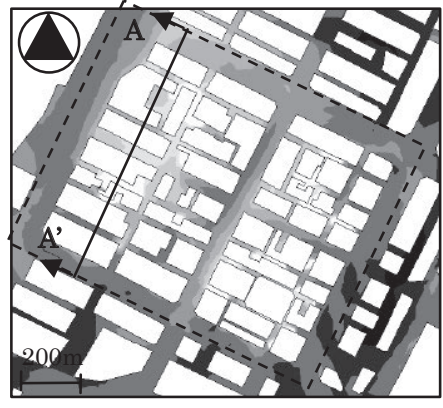

図 11 気温水平分布

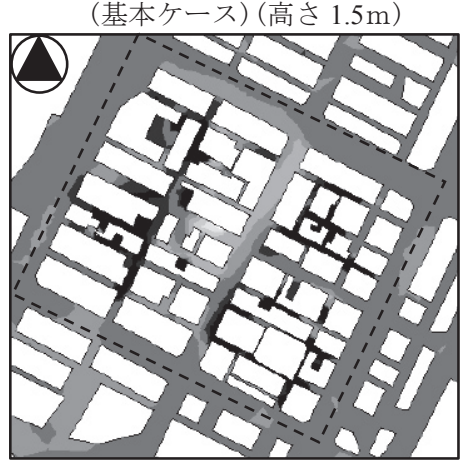

（2）屋上顕熱 10\% (Case2-2)

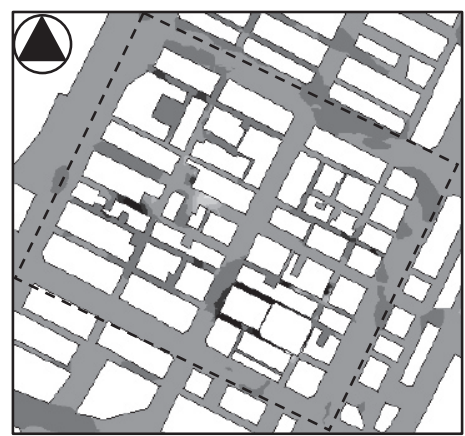

（4）屋上緑化（Case2-4）

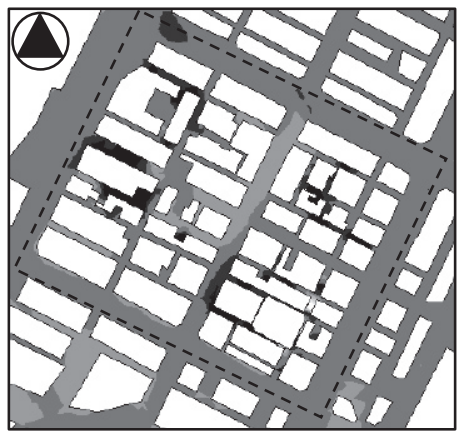

（7）道路高反射（Case2-7）

図 14 基本ケースとの温度差（高さ $1.5 \mathrm{~m}$ )

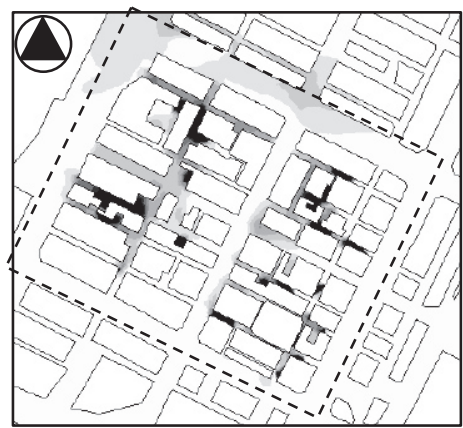

（2）空調排熱

図 15 影響度の水平分布(高さ $1.5 \mathrm{~m}$ )

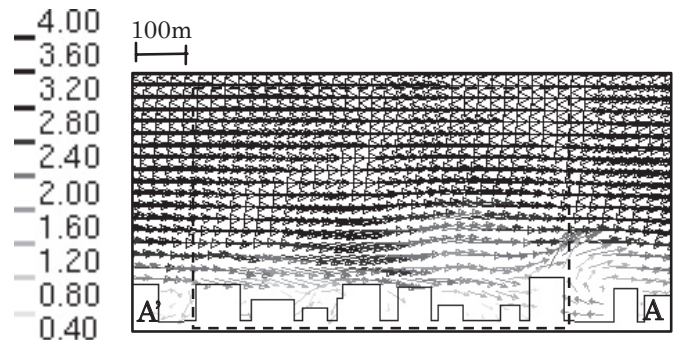

図 12 風速ベクトル鉛直分布

( $\mathrm{A}^{-\mathrm{A}^{\prime}}$ 断面)

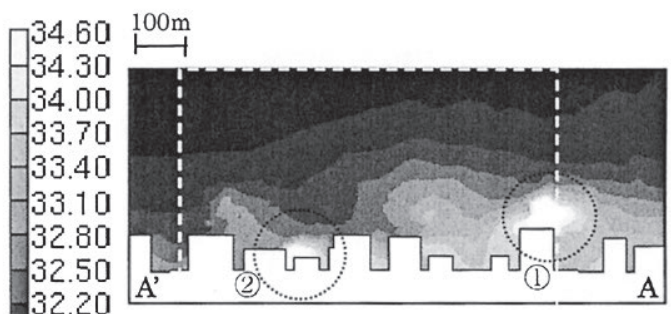

図 13 気温鉛直分布

( $\mathrm{A}^{-\mathrm{A}^{\prime}}$ 断面)

31.90
31.60 $\left[{ }^{\circ} \mathrm{C}\right]$

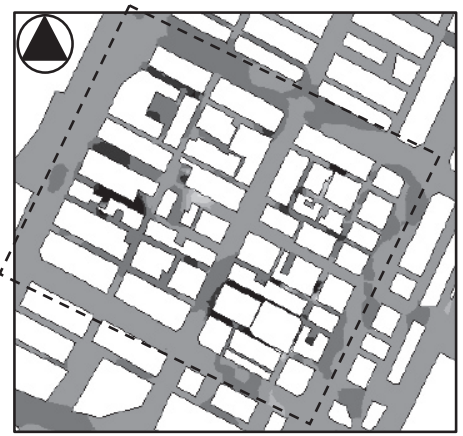

（5）屋上高反射 (Case2-5)

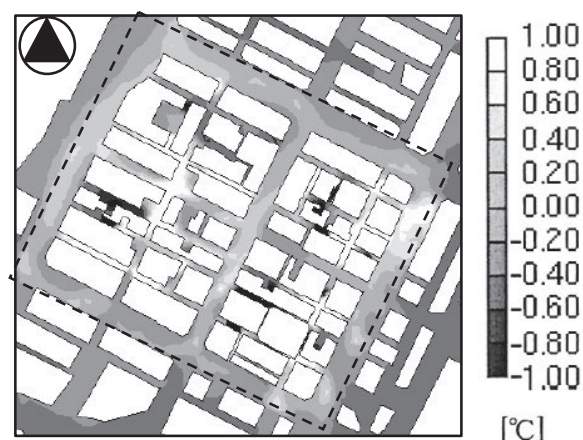

（8）交通排熱（Case2-8）

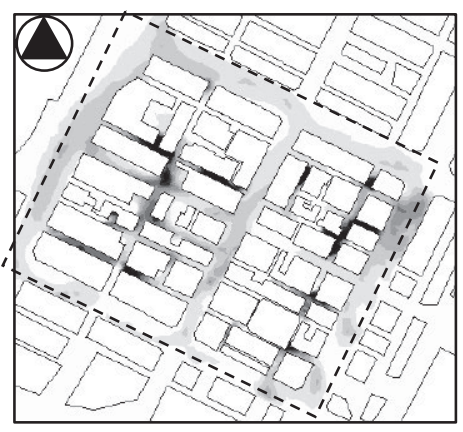

（3）交通排熱

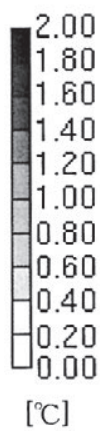

$\left[{ }^{\circ} \mathrm{C}\right]$ 
いためと考えられる。道路・敷地被覆条件を変えたケースでは、平均 気温は $0.03 \sim 0.14\left[^{\circ} \mathrm{C}\right]$ 低下し、交通排熱を考慮したケースでは検討対 象領域の平均気温は約 $\left.0.2{ }^{\circ} \mathrm{C}\right]$ 上昇した。(3)屋外温熱環境への影響 度: 図 9 に高さ $1.5[\mathrm{~m}]$ における屋外温熱環境への影響度の水平分布を 示す。表 8 に検討対象領域高さ $1.5[\mathrm{~m}]$ における影響度の平均值を示す。 建物全体の影響度を見ると、風下側では高層建物後ろの循環流の影響 により、壁面からの顕熱フラックスが蓄積され、影響度が増大する傾 向が見られる。建物全体の影響度の検討対象領域の平均值は約 $0.2^{\circ} \mathrm{C}$ 程度であり、交通排熱の影響度と同じ程度になった。空調排熱の影響 度は小さい值となった。これは高層建物の屋上からの空調排熱は上空 へと排出され、地表面付近への影響が小さいためと考えられる。

\section{2 京橋}

（1）風速：図 10 に基本ケースの高さ $1.5[\mathrm{~m}]$ における風速ベクトル水 平分布を示す。全ケースにおいて幅の狭い路地では風速が小さく、 幅の広い道路では大きくなる傾向がある。図 12 に風速ベクトル鉛直 分布 (A-A “断面) を示す。水平分布同様に全ケースで同様の傾向が 見られた。しかしながら、空調排熱の有無によって、排熱口付近の風 速は分布に局所的な変化が見られた。表 9 に各ケースの高さ $1.5[\mathrm{~m}]$ における検討対象領域の水平面平均風速を示す。基本ケースと比較す ると、空調排熱がないため、Case2-0 では平均風速が約 $0.3[\mathrm{~m} / \mathrm{s}]$ 低下 する。Case2-4，2-5、2-6 の被覆条件の変化ではほとんど平均風速は 変化しないが、Case2-7 の道路高反射化では若干上昇する結果となっ た。Case2-8 では道路からの熱フラックスにより、平均風速が約 $0.1[\mathrm{~m} / \mathrm{s}]$ 増加した。

(2) 気温: 図 11 に高さ $1.5[\mathrm{~m}]$ における基本ケースの気温水平分布を 示寸。各層に側面排熱があるため局所的に気温が高くなり、特に幅の 狭い路地では顕著であった。図 13 に気温鉛直分布を示す。屋上から 空調排熱（点線部(1)）、側面からの空調排熱（点線部(2)）付近で気温 が局所的に上昇していることがわかる。また、側面排熱からの熱が滞 留し、人体領域も含めて道路全体の気温が上昇していることがわかる。 図 14 に、高さ $1.5[\mathrm{~m}]$ における各ケースと基本ケースとの気温差を示 す。Case2-2, 2-3 をみると、各層の側面排熱が建物間の路地空間の気 温上昇に大きな影響を与えていることがわかった。続いて Case2-4、 Case2-5 の屋上被覆対策は、人工排熱の削減よりも影響は小さいが、 最小 $1\left[{ }^{\circ} \mathrm{C}\right]$ 程度気温が低下しており、大手町の場合と比べると大きな 効果がある。これは京橋地区の建物の屋上位置が大手町に比べて低い のと、屋上高さが不均一であることにより、屋上付近で低下した気温 がより活発に地表面付近へ輸送されたものと考えられる。逆に、 Case2-6、Case2-7 では道路被覆対策により道路・敷地の表面温度が低 くなっているため、領域全体の気温が低下寸る傾向がみられた。 Case2-8 では、交通排熱が解析領域全体の気温を上昇させていること がわかった。交通排熱が幅の狭い路地に流れ込み滞留するため、風通 しのよい幅の広い道路は気温上昇が比較的抑えられているが、幅の狭 い路地では交通排熱がないにもかかわらず気温上昇が起こることが わかった。表 9 の水平面平均気温をみると、基本ケースに比べ屋上排 熱ケース(Case2-2,2-3)では平均気温が $0.2\left[{ }^{\circ} \mathrm{C}\right]$ 程度低下した。これに対 して、屋上被覆対策ケース (Case2-4、2-5) では基本ケースと同じ值を 示し、道路・敷地被覆対策ケース (Case2-6、Case2-7)では、基本ケー スより $0.1\left[{ }^{\circ} \mathrm{C}\right]$ 程度平均気温が低下し、歩行者レベルに対する屋外温 熱環境の緩和効果が示された。交通排熱を考慮したケース (Case2-8)
では、基本ケースより約 $0.4\left[{ }^{\circ} \mathrm{C}\right]$ 平均気温が上昇する結果となった。 （3）屋外温熱環境への影響度:図 15 に高さ $1.5[\mathrm{~m}]$ での影響度を示す。 表 10 に高さ $1.5[\mathrm{~m}]$ における検討対象領域の平均影響度を示す。建物 全体の影響度は風下を中心とした広い範囲で約 $1.0\left[{ }^{\circ} \mathrm{C}\right]$ であり、領域 における平均影響度は約 $0.3\left[{ }^{\circ} \mathrm{C}\right]$ である。各壁面を比べると、表面温 度が高くなる南面、西面および屋上面の影響度が大きいことがわかっ た。空調排熱の影響度は、一部で $2.0\left[{ }^{\circ} \mathrm{C}\right]$ 以上の影響度となるなど、 局所的に影響を与えることがわかった。空調排熱の平均影響度は $0.2\left[{ }^{\circ} \mathrm{C}\right]$ 程度であり、大手町地区の $0.019\left[{ }^{\circ} \mathrm{C}\right]$ に比べると非常に大きく 空調排熱対策が相対的に重要であることが予想できる。交通排熱では、 道路を中心とした広い領域で影響度が大きい。幅の広い道路では熱つ ラックスを出しているにもかかわらず、風通しが良いため広い領域で 影響度は $1.0\left[{ }^{\circ} \mathrm{C}\right]$ 以下となる。一方、風通しが悪い幅の狭い路地では、 幅の広い道路から熱が流れ込み蓄積されるため、影響度が大きくなる 傾向がある。平均影響度は最も大きい約 $0.4\left[{ }^{\circ} \mathrm{C}\right]$ となった。

\section{5. まとめ}

（1）実在街区の大手町地区、京橋地区を対象に放射・対流連成シミュ レーションを行い、屋上被覆及び道路・敷地被覆対策、空調排熱、交 通排熱が屋外温熱環境に及ぼす影響について検討を行った。

(2)高層業務街区では、建物壁面の影響度が大きく、平均影響度は交 通排熱と同じ程度になり、建物全体からの顕熱フラックスの影響が無 視できないことが分かった。従って、大手町のような高層オフィス街 区では、道路・敷地の被覆対策と交通排熱対策が歩行者レベルの温熱 環境緩和効果に有効である。

(3)中層業務街区では、建物壁面に比べて空調排熱の影響度が大きく、 風通しが悪いために地面からの顕熱、交通排熱がたまりやすい。また 高層業務街区に比べて屋上被覆の対策は一定の効果を有する。従って 道路・敷地被覆対策、空調排熱・交通排熱対策が有効である。

\section{参考文献}

1）村上他、ヒートアイランド現象緩和に関する評価システム CASBEE-HI の 開発、建築学会技術報告集、第 23 号、pp.247、2006.6

2）陳他、建物壁面からの顕熱放散や建物の人工排熱の屋外温熱環境に関する 影響度の研究（その 1)、空気調和・衛生工学会学術講演会講演論文集、 pp.2197-2200、2005

3）中嶋他、建物壁面からの顕熱放散や建物の人工排熱の屋外温熱環境 に関す る影響度の研究（その 2)、空気調和・衛生工学会学術講演会講演論文集、 pp.2201-2204、2005

4）陳他、建物壁面からの顕熱放散や建物の人工排熱の屋外温熱環境形成に関す る影響度の研究（その 3)、空気調和・衛生工学会学術講演会講演論文集、 pp.1473-1476、2006

5）国交省・環境省、平成 15 年度都市における人工排熱抑制によるヒートアイ ランド対策調査報告書、2003、環境省.(オンライン)、入手先 <http://www.env.go.jp/air/report/h16-05/>、(参照 2008-01-30)

6）原山他、非定常な対流・放射・伝導を考慮した屋外温熱環境予測評価手法に 関寸る研究 (その 2)、非定常伝熱解析への対流計算の組み込みと実在街区 を対象とした予測手法の精度検証、空気調和・衛生工学会学術講演会講演 論文集、pp.645-648、2001

7) 日本建築学会、建築物荷重指針・同解説、2004

8）原山他, 屋外温熱環境形成寄与率 $\mathrm{CRO}$ に関寸る研究 (その 3), 日本建築学 会大会学術講演梗概集, D1, pp.925-926, 2002

（2007年12月10日原稿受理，2008年 4 月24日採用決定） 